\title{
Effect of Fertility Levels on Growth, Phenological Parameters, Yield and Quality of Lentil (Lens culinaris medikus)
}

\author{
Sarita Patel*, Sanjeev Kumar Singh, T. Singh and Neeraj Singh \\ Department of Agronomy AKS, UNIVERSITY Satna (M.P.) 485001, India \\ *Corresponding author
}

\section{Keywords}

Fertility levels, CGR, RGR, LAI, Branches, Yield

Article Info

Accepted:

15 February 2019

Available Online:

10 March 2019

\section{A B S T R A C T}

A field experiment was conducted during Rabi season at AKS University Satna (M.P.) during 2016-2017, the experiment consist of three factors viz. four Nitrogen levels (N10, $\mathrm{N} 20, \mathrm{~N} 30$ and N40), four phosphorus levels (P50, P60, P70 and P80) and four potash levels (K10, K20, K30 and K40) was laid out in a randomized block design. with the objective of studying the effect of fertility levels on growth parameters (plant height, no. of branches per plant, no. of nodules per plant, fresh weight, dry weight), phenological parameters (LAI, CGR, RGR) and yield parameters ( no. of pods per plant, number of seeds per pod, seed weight, seed yield, test weight (1000 seeds) straw yield of lentil. The study relieved that increased growth parameters (plant height, no. of branches per plant, no. of nodules per plant) showed significant and consistent increased at all growth stages up to $30 \mathrm{~kg} \mathrm{Nha}^{-1}, 70 \mathrm{~kg} \mathrm{Pha}^{-1}, 30 \mathrm{Kkg} \mathrm{ha}^{-1}$, whereas phenological parameters and yield parameters increased significantly with Nitrogen application up to $40 \mathrm{~kg} \mathrm{Nha}^{-1}$, up to $80 \mathrm{~kg}$ $\mathrm{Pha}^{-1}$ and $40 \mathrm{~kg} \mathrm{~K} \mathrm{ha}^{-1}$. The interaction effect on seed yield is between N, P \& K was significant where highest with treatment combination of $40 \mathrm{~kg} \mathrm{~N}+80 \mathrm{~kg} \mathrm{P}^{-1}$ and of 40 $\mathrm{kg} \mathrm{ha}^{-1}$ respectively.

\section{Introduction}

Lentil (Lens culinaris madikus) a name given by the German botanist medikus in 1778 (Cubero, 1981). The primary product of the cultivated lentil is the seed, which is a valuable human food product containing a high amount of protein (22.0-34.5\%), carbohydrates $(65 \%)$ and other minerals and vitamins (Yadav et al., 2007) since, 2008. In many sentries lentils are used as a meat substitute (Duke, 1981). The seeds are mostly eaten as dal in soups and the flour can be mixed with cereal flour and used in cakes, breads and some baby food (Muehlbauer et al., 1995). In some parts of India, the whole seeds are eaten salted and fried young pods can also be used as green vegetables and the seeds can be a source of starch for textile and printing industries (Duke, 1981).

Lentil is predominantly grown in Asia which accounts for 80 percent of global area and $75 \%$ of world production. India ranks fist in area as well as production, in Lentil followed by Turkey. It occupies second place among 
the winter pulses after chickpea in the country covering an area of $1.48 \mathrm{~m}$ ha with a production of $1.03 \mathrm{~m}$ tones (Anonymous, 2011). The major lentil producing states are utter Pradesh, Madhya Pradesh, Bihar, West Bengal, Rajasthan and Assam.

Most of the pulse growing soils are deficient in available $\mathrm{P}$ status. Many field experiments conducted in different agro climatic regions of the country have unambiguously crop is an economically viable proposition. Application of $\mathrm{P}$ to the pulse crop not only increased their productivity but also gives considerable residue for succeeding crop. Phosphorous also improves the crop quality and enhances the crop resistance to diseases (Mann, 1968). Phosphate application to pulses not only benefit the particular crop in increasing its yield but also favorably affects the soil nitrogen content for the succeeding non legume crop which require lower doses of nitrogen application Potash is important in nitrogen fixation on lentil and it is important in protein, starch synthesis, water nutrient, sugar transport and crop quality improving on lentil. Consider as reaction catalyst and it affects the efficiency of various enzymes.

\section{Materials and Methods}

The investigation reported in the manuscript was carried out the experiment was conducted at the Instructional cum research farm, AKS University, Sherganj, Satna (M.P.) for rabi season 2016-2017. The experimental site is situated at the latitude of $23^{\circ} 58^{\prime} \mathrm{N}$ and longitude of $80^{\circ} 81^{\prime}$ east in mid northern part of rewa. The experimental farm lies in humid sub- tropical with an average rainfall is $1077 \mathrm{~mm}$ and mean temperature range from $21^{\circ} \mathrm{c}$ to $31^{\circ} \mathrm{c}$ during crop season $\mathrm{A}$ field experiment was conducted in factorial randomized block design using three varieties of lentil (PL-4, Rani K-75, HUL-57) and different NPK dose of
$\mathrm{F}_{1}=10: 50: 10 \mathrm{NPK} / \mathrm{ha}, \mathrm{F}_{2}=20: 60: 20 \mathrm{NPK} / \mathrm{ha}, \mathrm{F}_{3}=$ 30:70:30NPK/ha, $\mathrm{F}_{4}=40: 80: 40 \mathrm{NPK} / \mathrm{ha}$ as test crop at Agricultural Research Farm of AKS University, Sherganj, Satna (M.P.). The surface soil $(0-15 \mathrm{~cm})$ samples collected from the experimental farm were analyzed for physico- chemical properties as suggested by Jackson (1973). The soil was well drained, sandy loam in texture having $\mathrm{pH} 7.5$, EC 0.16 $\mathrm{dsm}^{-1}$, organic carbon $0.30 \mathrm{~g} \mathrm{~kg}^{-1}$, available nitrogen $176.6 \mathrm{~kg} \mathrm{ha}^{-1}$, available phosphorus $12.5 \mathrm{~kg} \mathrm{ha}^{-1}$ and available potassium $200 \mathrm{~kg}$ $\mathrm{ha}^{-1}$. NPK was applied through urea, single super phosphate, muriate of potash and elemental sulphur, respectively. As per treatments, basal dressing along with $1 / 2$ dose of nitrogen, full dose of phosphorus and potash at the time of sowing and remaining $1 / 2$ dose of $\mathrm{N}$ was applied at 30 days after sowing (DAS). The crop was sown in spacing (30x5 $\mathrm{cm}$ apart) on 15 November, 2016. All agronomic practices were kept uniform and normal for all treatment. Data on plant height (cm) number of branches per plant, number of nodules per plant, fresh weight of nodules ( $\mathrm{g}$ plant) dry matter accumulation (g plant-1/Q ha ${ }^{-1}$ ), leaf area index, number of pods per plant, number of seeds per pod, 1000- seed weight $(\mathrm{g})$ seed yield, straw yield and harvest index were recorded during the course study by following standard procedure. Harvested on 17 March 2017 at maturity yield attributing characters.

\section{Results and Discussion}

\section{Growth parameters}

These favourable soil conditions brought about efficient utilization of plant nutrients accompanied by activating plant enzymes. The higher fertility level $\left(\mathrm{N}_{30} \mathrm{P}_{70} \mathrm{~K}_{30}\right)$ increased all the growth parameters significantly at every stage of observations. Accordingly $\mathrm{N}_{30} \mathrm{P}_{70} \mathrm{~K}_{30}$ recorded maximum plant height $(61.84 \mathrm{~cm})$, branches (12.13/plant) and root nodules 
(25.0/plant) but LAI (3.76), CGR (0.0363 $\mathrm{g} / \mathrm{m}^{2} /$ day $)$, fresh weight $(11.20 \mathrm{~g} / \mathrm{plant})$, dry weight $(2.19 \mathrm{~g} /$ plant $)$ were found maximum due to highest fertility level $\left(\mathrm{N}_{40} \mathrm{P}_{80} \mathrm{~K}_{40}\right)$ (Table 1). On the other hand, the significantly lowest all these growth parameters were recorded under the lowest fertility level $\left(\mathrm{N}_{10} \mathrm{P}_{50} \mathrm{~K}_{10}\right)$ root development particularly due to increased availability of phosphorus insured more absorption of minerals, nutrients and soil moisture from the deeper soil layers. The remarkable increase in plant height and formation of higher number of branches/plant due to higher doses of phosphorus associated activities of Rhizobium and PSB biofertilizers supplying additional nutrients and solubilizedphosphorus may be as a result of acceleration of cell elongation and cell division. The present findings confirm with those of several research workers (Sayed, 1999; Saha et al., 2004; Singh et al., 2007; Singh et al., 2011, Saketet.al., 2014; and Singh and Singh, 2017).

\section{Phenological parameters}

LAI, CGR, RGR significantly increased with increased on fertility levels. The periodical observations recorded on lentil reveal that LAI, CGR, RGR were increased almost significantly due to application of higher levels of fertility $\mathrm{N}_{40} \mathrm{P}_{80} \mathrm{~K}_{40}$ at every stage. At harvest stage, the LAI 3.64 to 3.76, CGR 0.36 $\mathrm{g} / \mathrm{m}^{2} /$ day, RGR was not influenced significantly (Table 2-7).

\section{Yield parameters}

The factors which are directly responsible for ultimate grain production viz. number of pods/plant, number of grains /pod, and 1000grain yield were augmented almost significantly due to increased supply of NPK upto $\mathrm{N}_{40} \mathrm{P}_{80} \mathrm{~K}_{40}$ (Table 8).

Table.1 Plant height $(\mathrm{cm})$ of lentil at different growth intervals as influenced by fertility levels, varieties and their interactions

\begin{tabular}{|l|c|c|c|c|}
\hline Treatments & & \multicolumn{2}{|c|}{ Plant height (cm) } & \\
\hline & 30 & 60 & 90 DAS & At \\
\hline Fertility levels (kg/ha) & & & & Harvest \\
\hline N10P50K10 & 6.80 & 20.33 & 47.51 & 49.13 \\
\hline N20P60K20 & 7.47 & 22.75 & 58.22 & 59.87 \\
\hline N30P70K30 & & & & \\
\hline & 8.29 & 24.69 & 61.17 & 61.84 \\
\hline N40P80K40 & 7.64 & 22.69 & 55.93 & 57.80 \\
\hline S.Em \pm & 0.26 & 0.70 & 2.33 & 2.10 \\
\hline C.D. (P=0.05) & & & & \\
\hline & 0.77 & 2.06 & 6.84 & 6.22 \\
\hline
\end{tabular}


Table.2 Leaf area index (LAI) of lentil at different growth intervals as influenced by fertility levels, varieties and their interactions

\begin{tabular}{|c|c|c|c|}
\hline Treatments & & Leaf area inde & \\
\hline & 30 & 60 & 90 DAS \\
\hline Fertility levels & & & \\
\hline N10P50K10 & 0.59 & 1.29 & 3.41 \\
\hline N20P60K20 & 0.72 & 1.33 & 3.56 \\
\hline N30P70K30 & 0.77 & 1.39 & 3.64 \\
\hline N40P80K40 & 0.79 & 1.48 & 3.76 \\
\hline S.Em \pm & 0.07 & 0.027 & 0.070 \\
\hline C.D. $(P=0.05)$ & 0.0525 & 0.080 & 0.205 \\
\hline
\end{tabular}

Table.3 Crop growth rate [CGR $\left(\mathrm{g} / \mathrm{m}^{2} /\right.$ day)] of lentil at different growth intervals as influenced by fertility levels, varieties and their interactions

\begin{tabular}{|c|c|c|}
\hline \multirow[t]{3}{*}{ Treatments } & \multirow{2}{*}{\multicolumn{2}{|c|}{$\begin{array}{l}\text { Crop growth rate } \\
\left.\text { [CGR }\left(\mathrm{g} / \mathrm{m}^{2} / \text { day }\right)\right]\end{array}$}} \\
\hline & & \\
\hline & 30 & 60 DAS \\
\hline \multicolumn{3}{|c|}{ Fertility levels (kg/ha) } \\
\hline N10P50K10 & 0.021 & 0.0280 \\
\hline N20P60K20 & 0.023 & 0.0289 \\
\hline N30P70K30 & 0.025 & 0.0360 \\
\hline N40P80K40 & 0.026 & 0.0363 \\
\hline S.Em \pm & 0.0004 & 0.0015 \\
\hline C.D. $(P=0.05)$ & 0.0011 & 0.0043 \\
\hline
\end{tabular}


Table.4 Relative growth rate [RGR (g/plant/day)] of lentil at different growth intervals as influenced by fertility levels, varieties and their interactions

\begin{tabular}{|l|c|c|}
\hline Treatments & \multicolumn{2}{|c|}{ Relative growth rate } \\
\hline & $\mathbf{3 0}$ (g/plant/day) \\
\hline Fertility levels (kg/ha) & & $\mathbf{6 0}$ DAS \\
\hline & & \\
\hline N10P50K10 & 0.0447 & 0.0228 \\
\hline N20P60K20 & 0.0441 & 0.0020 \\
\hline N30P70K30 & 0.0431 & 0.0241 \\
\hline & & \\
\hline N40P80K40 & 0.0407 & 0.0229 \\
\hline & & \\
\hline S.Em \pm & $\mathbf{0 . 0 0 0 6}$ & $\mathbf{0 . 0 0 0 8 4}$ \\
\hline & & \\
\hline C.D. $(\mathbf{P}=\mathbf{0 . 0 5})$ & $\mathbf{0 . 0 0 1 7}$ & $\mathbf{N S}$ \\
\hline
\end{tabular}

Table.5 Fresh weight/plant of lentil at different growth intervals as influenced by fertility levels, varieties and their interactions

\begin{tabular}{|l|c|c|c|}
\hline Treatments & \multicolumn{3}{|c|}{ Fresh weight/plant (g) } \\
\hline & $\mathbf{3 0}$ & $\mathbf{6 0}$ & 90 DAS \\
\hline Fertility levels (kg/ha) & & & \\
\hline N10P50K10 & 1.31 & 4.18 & 8.12 \\
\hline N20P60K20 & & & \\
\hline N30P70K30 & 1.43 & 4.51 & 8.90 \\
\hline N40P80K40 & 1.55 & & 10.22 \\
\hline S.Em \pm & 1.63 & 5.53 & 11.20 \\
\hline C.D. $(\mathbf{P}=0.05)$ & & & $\mathbf{0 . 1 0 0}$ \\
\hline
\end{tabular}


Table.6 Protein content of lentil as influenced by fertility levels, varieties and their interactions

\begin{tabular}{|c|c|c|c|c|}
\hline Fertility levels & & Varieties & & \\
\hline \multirow{3}{*}{ (kg/ha) } & & & \multirow{3}{*}{ HUL-57 } & \multirow{3}{*}{ Mean } \\
\hline & \multirow[t]{2}{*}{ PL-4 } & \multirow{2}{*}{$\begin{array}{l}\text { Rani K- } \\
75\end{array}$} & & \\
\hline & & & & \\
\hline N10P50K10 & 20.07 & 21.10 & 22.18 & 21.12 \\
\hline N20P60K20 & 21.42 & 22.25 & 23.31 & 22.33 \\
\hline N30P70K30 & 22.64 & 23.17 & 24.10 & 23.30 \\
\hline N40P80K40 & 23.02 & 23.25 & 24.31 & 23.53 \\
\hline Mean & 21.79 & 22.04 & 23.48 & \\
\hline & Fertility levels & Varieties & $\begin{array}{l}\text { Interactio } \\
\mathbf{n}\end{array}$ & \\
\hline S.Em \pm & 0.084 & 0.073 & 0.145 & \\
\hline C.D. $(P=0.05)$ & 0.246 & 0.213 & NS & \\
\hline
\end{tabular}

Table.7 Growth parameters of lentil as influenced by fertility levels

\begin{tabular}{|c|c|c|c|c|c|c|c|c|}
\hline Treatments & $\begin{array}{l}\text { Plant } \\
\text { height } \\
(\mathrm{cm}) \text { at } \\
\text { harvest }\end{array}$ & $\begin{array}{c}\text { Branches } \\
\text { plant } 90 \\
\text { DAS }\end{array}$ & $\begin{array}{c}\text { Root } \\
\text { nodules/ } \\
\text { plant at } \\
\text { 45 DAS }\end{array}$ & $\begin{array}{l}\text { LAI } 90 \\
\text { DAS }\end{array}$ & $\begin{array}{c}\text { CGR } \\
\text { (g/m²/day) } \\
(60-90 \\
\text { DAS })\end{array}$ & $\begin{array}{c}\text { RGR } \\
\text { (g/plant/da } \\
\text { y) } \\
(60-90 \\
\text { DAS })\end{array}$ & $\begin{array}{c}\text { Fresh } \\
\text { weight/ } \\
\text { plant } \\
\text { (g) at } 90 \\
\text { DAS }\end{array}$ & $\begin{array}{c}\text { Dry } \\
\text { weight/ } \\
\text { plant }(\mathrm{g}) \\
\text { at } 90 \\
\text { DAS }\end{array}$ \\
\hline \multicolumn{9}{|l|}{$\begin{array}{l}\text { Fertility levels } \\
\qquad(\mathrm{kg} / \mathrm{ha})\end{array}$} \\
\hline N10P50K10 & 49.13 & 7.83 & 10.71 & 3.41 & 0.0280 & 0.0228 & 8.12 & 1.68 \\
\hline N20P60K200 & 59.87 & 9.89 & 13.96 & 3.56 & 0.0289 & 0.0220 & 8.90 & 1.79 \\
\hline N30P70K30 & 61.84 & 12.13 & 16.76 & 3.64 & 0.0360 & 0.0241 & 10.22 & 2.09 \\
\hline N40P80K40 & 57.80 & 9.04 & 12.62 & 3.76 & 0.0363 & 0.0229 & 11.20 & 2.19 \\
\hline S.Em \pm & 2.10 & 1.04 & 1.08 & 0.070 & 0.0015 & 0.00084 & 0.10 & 0.044 \\
\hline C.D. $(\mathrm{P}=0.05)$ & 6.22 & 3.05 & 3.17 & 0.205 & 0.0043 & NS & 0.29 & 0.130 \\
\hline
\end{tabular}


Table.8 Yield-attributes, yield and protein content of lentil as influenced by fertility levels

\begin{tabular}{|l|c|c|c|c|c|c|}
\hline Treatments & $\begin{array}{c}\text { Pods/ } \\
\text { plant }\end{array}$ & $\begin{array}{c}\text { Seeds/ } \\
\text { pod }\end{array}$ & $\begin{array}{c}\text { 1000-seed } \\
\text { weight/plant } \\
(\mathrm{g})\end{array}$ & $\begin{array}{c}\text { Seed } \\
\text { yield(q/ha) }\end{array}$ & $\begin{array}{c}\text { Straw } \\
\text { yield } \\
(\mathrm{q} / \mathrm{ha})\end{array}$ & $\begin{array}{c}\text { Seed } \\
\text { Protein } \\
(\%)\end{array}$ \\
\hline $\begin{array}{c}\text { Fertility levels } \\
(\mathrm{kg} / \mathrm{ha})\end{array}$ & & & & & & \\
\hline N10P50K10 & 124.36 & 1.30 & 22.15 & 9.11 & 17.01 & 21.12 \\
\hline N20P60K200 & 128.48 & 1.37 & 23.23 & 10.46 & 19.91 & 22.33 \\
\hline N30P70K30 & 135.26 & 1.44 & 24.22 & 11.46 & 21.80 & 23.30 \\
\hline N40P80K40 & 142.31 & 1.47 & 24.44 & 12.37 & 23.93 & 23.53 \\
\hline S.Em \pm & & & & & & \\
\hline C.D. $(\mathrm{P}=0.05)$ & 2.07 & 0.051 & 0.392 & 0.221 & 0.434 & 0.246 \\
\hline
\end{tabular}

The overall grain yield of lentil was found higher by $12.37 \mathrm{q} /$ ha due to $\mathrm{N}_{40} \mathrm{P}_{80} \mathrm{~K}_{40}$ over the $3,26 \mathrm{q} /$ ha due to $\mathrm{N}_{10} \mathrm{P}_{50} \mathrm{~K}_{10}$. Similarly straw yield is higher by $23.93 \mathrm{q} /$ ha due to $\mathrm{N}_{40} \mathrm{P}_{80} \mathrm{~K}_{40}$ over the $6.92 \mathrm{q} /$ ha due to $\mathrm{N}_{10} \mathrm{P}_{50} \mathrm{~K}_{10}$. The trend of increases in grain yield obtained due to this treatment was exactly in accordance with the similar increases recorded in the yieldattributing characters (pods/plant, seeds/pod and 1000-grain weight) and the increased vegetative growth.

\section{Quality parameters}

The protein content in grain was found to increase significantly (23.30 to $23.53 \%$ ) with the higher levels of fertility $\left(\mathrm{N}_{30} \mathrm{P}_{70} \mathrm{~K}_{30}\right.$ and $\mathrm{N}_{40} \mathrm{P}_{80} \mathrm{~K}_{40}$ ). The significantly lowest protein content (21.12\%). The response of NPK in improving seed quality may be attributed to its significant role in regulating the photosynthesis, root-enlargement and better microbial activities (Mishra et al., 2015). These results are in agreement with those of several workers (Saha et al., 2004; Singh et al., 2007; Tetarwal and Rana, 2007; Singh et al., 2011; Saket et al., 2014 and Singh and Singh, 2017).

\section{References}

Cubero, J.I. 1981. Orgin, taxonomy and domestication In: Lentils (eds C. Webb \& G.C. Hawtin). Commonwealth Agricultural Bureau, Slough, England.

Duke, J.A.1981.Handbook of legumes of world economic importance Plenum Press, New York.

Muehlbauer, F.J., Kaiser, W.J., Clement, S.L. and Summergield, R.J. 1995. Production and breeding of lentil. Advances in Agronomy, 54:283-332.

Saha, S., Mitra, B. and Rana, S.K. 2004. Effect of different levels of phosphorus and irrigation on the yield components and yield of lentil. Journal of Interacademicia, 8(1): 33-36.

Saket, Sukhlal, Singh, S.B., Namdeo, K.N. and Parihar, S.S. 2014. Annals of Plant and Soil Research, 16(3): 238-341.

Sayed, E.I. 1999. Influence of Rhizobium and phosphate-solubilizing bacteria on 
nutrient uptake and yield of lentil in New Valley. Egyptian Journal ofSoil Science, 39(2): 175-186.

Singh et al., 2007. Root growth, nodulation, grain yield and phosphorus use efficiency of lentil as influenced by phosphorus, irrigation and inoculation. Journal Communications in Soil Science and Plant Analysis, volume 36, 2005-issue 13-14.

Singh, G., Hari Ram, H.S., Agrawal, N. and Khanna, V. 2011. Effect of nutrient management on nodulation, growth and yield of lentil. Eurasian Journal of Agronomy, 4(3): 46-49.

Singh, R. and Singh, A.P. 2017. Effect of phosphorus, sulphur and biofertilizer on yield, quality and uptake of nutrients in cowpea. Annals of Plant and Soil Research, 19(2): 175-179.

Tetarwal, J.P. and Rana, K.S. 2007. Impact of cropping system fertility level and moisture conservation on productivity, nutrient uptake, water used and profitability of Mothbean under rainfed condition. Indian J.Agron., 51(4): 263266.

Yadav. S.S., Stevenson, P.C., Rizvi, A. H., Manohar, M., Gailing, S. and Mateljan, G. 2007. Uses and consumption In: Lentil. An ancient crop for modern times (eds S.S. Yadav, D.L McNeil, \& P.C. Stevenson). Spring, Dordrecht, The Netherlands.

\section{How to cite this article:}

Sarita Patel, Sanjeev Kumar Singh, T. Singh and Neeraj Singh. 2019. Effect of Fertility Levels on Growth, Phenological Parameters, Yield and Quality of Lentil (Lens culinaris medikus). Int.J.Curr.Microbiol.App.Sci. 8(03): 1728-1735. doi: https://doi.org/10.20546/ijcmas.2019.803.201 